\title{
Toward Territorial Cohesion with the National Spatial Plan for Albania 2030
}

\author{
Anisa Qorri ${ }^{1}$, Eled Fagu ${ }^{2}$ \\ ${ }^{1}$ National Territorial Planning Agency, Ministry of Urban Development, Albania, \\ ${ }^{2}$ Faculty of Architecture and Urbanism, Polytechnic University of Tirana, Albania
}

\begin{abstract}
In late 2013 the National Territorial Planning Agency (NTPA) in collaboration with the Ministry of Urban Development (MUD) of Albania took the initiative of drafting the First National Spatial Plan for Albania 2030(NSPA). The strong need of the country to jump to a new way of sustainable development was backed up by the political will and a new legal planning reform, paving the ground for new integrated planning instruments. Although this is not the first time plans are drafted in Albania this is the first national spatial plan for the country. The methodology for drafting the NSPA was based on three complementary steps: At first the metabolic analysis of the territory was performed for five main systems of the territory: water, food, infrastructure, urban and natural system. Secondly, the Declaration of Vision was drafted through a wide participatory process from different stakeholder form the government administration but also independent experts and academia. Third, the strategic proposals through flexible tools that allow for further exploration for best collaboration between national developing sectors and local governance. The plan followed an open and democratic approach reflected not only in the participatory drafting process but also on the strategic proposals that were offered. It was not the aim of the working group to have a restrictive plan with rigid land use maps but to provide a tool for the national and local administration and also private sector that would guide and advise on the best possible uses of the territory. The plan gives alternatives and describes possibilities for best cross-sector and inter-regional cooperation and proposes strategic projects of national importance for the sustainable development of the territory in the next 15 years. Major public hearing were held across the country, so people could have the chance to express ideas, to be informed but above all to be part of a national plan that would guide the territorial development for the next 15 years. The participation process resulted to a new increased level of awareness of the importance of territorial planning as a cohesive process to different governance sector of the administration. Strengthen institutional capacity for cross-cutting issues of territorial planning resulted essential to achieve a plan that aimed spatial balance, sustainable development, and socio-economic wellbeing. Even though the NSPA is approved at the highest instances foreseen by the law, for the actual administration it is an ongoing process and its success depends on a large scale on continuous research of contextual planning issues and for every stage of its implementation or upgrade to assure an open transparent inclusive process with democratic participation.
\end{abstract}

Keywords: National Spatial plan, territorial cohesion, participatory planning, governance policy

\section{Introduction}

Even though Territorial Cohesion concept is not new as such first mentioned more than two decades ago in the Treaty of Amsterdam 1994 [4], [3], [10] than introduced in the European Spatial Development Perspective [2] as a decisive milestone presenting the 'territory' as a 'new dimension of the European Policy', it gained the attention for elaboration into an applicable concept only in 2004 in the Rotterdam Acquis. It was then launched as one of the three main pillars of the European Union Cohesion Policy with the Green Paper on Territorial Cohesion [9], and it was included in the Lisbon Treaty, in 2009, [7] [10].

The debate of recent years has shown that a strict definition of territorial cohesion is difficult and sometimes impossible [1] [5]. Although "Territorial cohesion is merely said to augment existing policies with a greater focus on development opportunities, to encourage co-operation and net- working, to pay greater attention to strengths of areas and by a better targeting of policy instruments". Rather than giving a definition, the message seems to be that nothing radically new is being proposed [3]. As main stakeholders emphasize different dimensions of the territorial cohesion idea, and because the concept has to be fluid enough to accommodate temporal change, any attempt to define it precisely will unavoidably result in excluding certain senses or aspects and thus lead to a poorer result [1].

Within the above context of latest regional discussions on territorial development concepts, when it comes to Albania, we may confirm that territorial cohesion is about a totally novel concept and uncharted field.

While it is not the aim of this paper to explore the origin, meaning and importance of territorial cohesion as this is a concept largely argued and previously explored in the EU context, it is in the focus to describe the relation and the rescale of EU spatial planning concepts on the national state level of the planning framework for Albania.

It is important to explore how this concept, fundamentally created as an instrument for territorial management within the member states and further more to formalize the role of the European Union in the competence of planning, serves as a strong guidance and shapes the highest levels of policy documents even for the states outside the EU such as Albania. The case is relevant to be explored on different levels. First, in the light of the EU enlargement dilemmas, the correct implementation of territorial cohesion policy can foster positive actions toward member and non member state cooperation.

Secondly, EU policies main aims and objectives can be better 


\section{International Journal of Science and Research (IJSR) \\ ISSN (Online): 2319-7064}

Index Copernicus Value (2016): 79.57 | Impact Factor (2015): 6.391

tested their effectiveness when applied downscaled on a state level.

The paper presents an analysis of the National Territorial Plan of Albania 2030 with main reference on the Territorial Cohesion key characteristics. The focus is placed upon the planning practices, by analyzing the case of the National Territorial Plan in relation to the main elements of Territorial Cohesion policy.

The importance of the study case stands in showing how European-level territorial policies can be adopted and downscaled on a national level of a country. And above all, when talking about territorial cohesion in Europe, "integration is a state of mind". Spreading knowledge and advancing with new concepts within the common interest of sustainable development overcomes borders.

\section{The context of drafting a national territorial plan and the relation to territorial cohesion}

It is understandable that Albania's long-term aspiration to join the EU since long has adopted a large number of European legal directives, but while the ESDP and Territorial Cohesion Policy are not a requirement even for European member countries, in Albania it has found a broad implementation that starts from the reformed legal planning framework, to the drafting of the new planning documents.

Of course, there are a lot of challenges for Albania when looked from the perspective of catching up with the rest of the other countries of Europe in terms of economic performance but on the other hand, it is worth mentioning that many European countries are still facing the same challenges as Albania in terms of overcoming spatial disparities, securing sustainable development and conservation of environmental sensitive areas, as well as fair access to services, and achieving territorial resilience, at a national level also at the European level.

As territorial cohesion is about place based policy making, paying particular attention to local development conditions, going below the regional level [1], the policies of member states on territorial cohesion that address the spatial disparities issues are useful and make sense when applying their actions and measures even at a level state. If the country is a member of the EU or not, it should not be a limitation to their implementation, because when it comes to environment, climate change effects but also on an everyday growing virtual market economy, issues have no physical boundaries.

In this background it is important to deepen the research on clearly identify those spatial policies that when downscaled at a state level planning documents can contribute to the main goals of territorial cohesion. Furthermore, as a policy that is nonbinding on EU member states, how it still can influence and be adopted to the main planning documents of nonmember countries. In the text a subtle feature comes out that accompanies or in some cases even conditiones the implementation of cohesive of territorial policies: it is the Political support. Then, this raises the question: How can a non-member country strengthen the role of planning institutions and authorities so that principles of territorial cohesion lead the policy making and be more resilient to it? Or how do the documents based on territorial cohesion affect the strengthening of this feature? Could the acquisition of the Cohesion Policy incentivize stronger, competent and conscientious institutions that formulate and guide political decisions? The above questions are seen in the case of drafting and empowerment of the National Plan for Albania 2030, as the highest planning instrument in the country.

Below are described, the three main contextual elements that have enabled this approach in the NSP of Albania 2030: the legal framework of the territorial planning reform, accountable and responsible planning authorities and the administrative reform, developed at a same time frame 2013 2016.

Legal context: Although the evolution of the planning system in Albania from urbanism to territorial planning has been analyzed before [6], it should be noted that by 2013 the planning reform process initiated from 2006 was not yet completed. Although in force, the innovative law that introduced and paved the way for the application of new territorial planning instruments, it could not be fully implemented in the absence of detailed regulations and planning documents. In this way, at the end of 2013, initiated as a top down incentive of the political force at that moment, a comprehensive realization of the legal reform in the area of territorial planning. This meant not only completing the law with by laws bat also delivering manuals for better implementation and understanding the new planning concepts, for experts and local administration. Within the same years several initiatives were taken regarding the completition of planning documents as the NSP 2030, Integrated Coastal Plan for Albania, and Integrated Cross Sectorial Plan for the area of Tirana - Durres. This was a very decisive moment since the design of the NSP was directly linked to the law enforcement.

Administrative reform: The drafting of the NSP came at a decisive moment of when Two other key reforms on territorial development were launched : the Administrative Territorial Reform, that reorganized the territorial administration at the local level from 365 municipalities and communes to 61 municipalities and the Territorial Regionalization Reform, which defined the middle level of territorial organization for cohesive development into four main regions.

The NSP is of primary importance to the success of these reforms, because its approval ensures a coherent planning from the national level to the regional and local level. However, analysis of the way these processes were accomplished is not subject to this paper. Here is stressed the importance and the relation of this favorable legal and political context for the drafting of a national spatial plan, where the demand for a unified vision of national sectorial policies was imminent. It should be noted that the process of drafting and co-ordination of the NSP by involving all the actors on all levels of administration and academia, also the public participation on public hearings in thirteen main cities

\section{Volume 6 Issue 12, December 2017}




\section{International Journal of Science and Research (IJSR) \\ ISSN (Online): 2319-7064}

Index Copernicus Value (2016): 79.57 | Impact Factor (2015): 6.391

of the country, was by no means a simple and unobtrusive process. The new context described above and the wellprepared working team positively influenced for its realization.

Institutional reform: In 2013 a new Ministry dedicated exclusively to territorial management(while formerly the territory was an issue under public work ministry) was established Ministry of Urban Development (MUD), dedicating its work on the main problems that impact the national territory facing: informal settlements, social housing and of course territorial planning. Also the role of National Territorial Planning Agency (NTPA) was enforced as the main institution that would assure the horizontal and vertical coordination of national and local authorities that had a say on territory planning and development (ministries, national agencies and municipalities) having a holistic approach on territorial management of the territory from the main perspectives legal, territory administration and governmental authorities goes in line with the main territorial cohesion policies aims and objectives.

The approximation of Albanian NSP with the territorial cohesion objectives can be further identified when compared to actions promoted under the heading of "territorial cohesion":

Table 1: NSP Albania 2030 actions and Territorial Cohesion relation

\begin{tabular}{|c|c|c|}
\hline 1. & $\begin{array}{l}\text { Actions } \\
\text { promoted } \\
\text { under the } \\
\text { heading } \\
\text { "territorial } \\
\text { cohesion" }\end{array}$ & $\begin{array}{l}\text { NSP actions and Territorial Cohesion } \\
\text { relation }\end{array}$ \\
\hline 2. & $\begin{array}{l}\text { Smart growth } \\
\text { in } \\
\text { competitive } \\
\text { polycentric } \\
\text { Europe }\end{array}$ & $\begin{array}{l}\text { To reach the level of polycentrism at the } \\
\text { national level is proposed the } \\
\text { hierarchization of urban centers and the } \\
\text { identification of regional development } \\
\text { poles [8] : For purposes of this plan, } \\
\text { urban centers and their hierarchies is } \\
\text { based on central place theory, but is } \\
\text { enriched with reflections that derive from } \\
\text { additional dynamic functions such are } \\
\text { related with: } \\
\text { - Existing and proposed national } \\
\text { infrastructure; } \\
\text { - Concentration and the characteristic of } \\
\text { deployment in relation to natural } \\
\text { resources; } \\
\text { - Balancing pressures and demands for } \\
\text { urban development mainly in the western } \\
\text { part; } \\
\text { - Mitigating the tendencies of } \\
\text { depopulation and poverty mainly in the } \\
\text { peripheral eastern regions, orienting the } \\
\text { spatial dimension of economic } \\
\text { development policies on economies of } \\
\text { agglomeration from central places to } \\
\text { … evolving from } \\
\text { regional development poles. }\end{array}$ \\
\hline 3. & $\begin{array}{l}\text { Inclusive, } \\
\text { balanced } \\
\text { development }\end{array}$ & $\begin{array}{l}\text { NSP is about balanced development, } \\
\text { focusing on providing } \\
\text { inclusive growth, fair access to }\end{array}$ \\
\hline
\end{tabular}

\begin{tabular}{|c|c|c|}
\hline & $\begin{array}{l}\text { and fair access } \\
\text { to services }\end{array}$ & $\begin{array}{l}\text { infrastructure services and the reduction } \\
\text { of spatial disparities. This dimension of } \\
\text { NSP is embodied in the entire document } \\
\text { but it appears more clearly when } \\
\text { presenting projects that promote growth } \\
\text { and access on underdeveloped areas } \\
\text { (North, north- east and south east), with } \\
\text { the east corridor and transversal corridors } \\
\text { that assures accessibility and permeability } \\
\text { to the territory and the urban settlements. } \\
\text { Add public services on balanced } \\
\text { distributed primary urban centres, and } \\
\text { draws attention on providing appropriate } \\
\text { connections of these centres with the } \\
\text { areas and urban settlements around them. }\end{array}$ \\
\hline 4. & $\begin{array}{l}\text { Territorial } \\
\text { diversity and } \\
\text { the } \\
\text { importance of } \\
\text { local } \\
\text { development } \\
\text { conditions }\end{array}$ & $\begin{array}{l}\text { Territorial cohesion is about place-based } \\
\text { policy making, paying particular attention } \\
\text { to local Development conditions } \\
\text { ()Particular attention in the NSP is given } \\
\text { to the specificities of places and their } \\
\text { comparative advantages in chapter } 4 \\
\text { when exploring potentials and proposing } \\
\text { for developing Regional Growth Poles } \\
\text { and the specialized ones, according to } \\
\text { territorial specifies. }\end{array}$ \\
\hline 5. & $\begin{array}{l}\text { Geographic } \\
\text { specificities }\end{array}$ & $\begin{array}{l}\text { The NSP organizes the territory based on } \\
\text { five territorial systems: urban, natural, } \\
\text { agricultural, water and infrastructural[8]. } \\
\text { Approaching in base of territorial systems } \\
\text { implies the recognition and organization } \\
\text { of the territory through networks, } \\
\text { corridors, spaces and nodes, } \\
\text { interdependently linked by flows. These } \\
\text { systems are organized in relationships } \\
\text { between centers, corridors and areas on } \\
\text { the basis of which the planning } \\
\text { documents of the lower hierarchies will } \\
\text { be detailed. They do not define the } \\
\text { territory in rigid land use proposals, but } \\
\text { describe and present different ways and } \\
\text { possibilities of developing economic } \\
\text { activities that go in line with the primary } \\
\text { characteristics of the territories and by } \\
\text { mutual way of cooperation. }\end{array}$ \\
\hline 6. & $\begin{array}{l}\text { Environmenta } \\
1 \text { dimension } \\
\text { and } \\
\text { sustainable } \\
\text { development }\end{array}$ & $\begin{array}{l}\text { Environment and nature, because of their } \\
\text { largely interaction character, consist in a } \\
\text { network that do not belong exclusively to } \\
\text { one territory or a group of population, } \\
\text { they are part of a wider system. The } \\
\text { concept of using resources that we do not } \\
\text { own, but share it in time and space is } \\
\text { essential in territorial development } \\
\text { policies. The most typical example of this } \\
\text { interaction is the impact on climate } \\
\text { change experienced by different countries } \\
\text { and peoples due to the inadequate } \\
\text { exploitation of non-renewable resources } \\
\text { and environmental pollution. The NSP is } \\
\text { associated with the drafting of } \\
\text { Environmental Impact Assessment that } \\
\text { addresses measures and actions that } \\
\text { define the way of NSPs policies } \\
\text { implementation to assure environmental } \\
\text { protection. }\end{array}$ \\
\hline 7. & $\begin{array}{l}\text { Governance, } \\
\text { coordination } \\
\text { of policies } \\
\text { and territorial }\end{array}$ & $\begin{array}{l}\text { Territorial cohesion is about the need to } \\
\text { maintain dialogue with other sectors to } \\
\text { strengthen the territorial dimension in } \\
\text { various policy fields. This coordination is }\end{array}$ \\
\hline
\end{tabular}




\section{International Journal of Science and Research (IJSR) \\ ISSN (Online): 2319-7064}

Index Copernicus Value (2016): 79.57 | Impact Factor (2015): 6.391

\begin{tabular}{|l|l|}
\hline impacts & $\begin{array}{l}\text { ensured not only during the process of } \\
\text { drafting the plan through public } \\
\text { consultations and institutional } \\
\text { coordination but also through the } \\
\text { functions of a central government } \\
\text { institution such as the NTPA, whose } \\
\text { primary legal task is to ensure a } \\
\text { coordinated process vertically and } \\
\text { horizontally, transparently and in } \\
\text { compliance with the applicable legal } \\
\text { framework ( Article 4 Law } \\
\text { 107/2014)Broadly speaking, the topic } \\
\text { focus on governance and cooperation } \\
\text { processes - as a key aspect of territorial } \\
\text { cohesion - rather than actual territorial } \\
\text { development features. }\end{array}$ \\
\hline
\end{tabular}

NSP can relate more to territorial cohesion. Firstly, it established an inter-institutional communication network and linked experts and technicians of public administration in a dialogue and collaboration beyond formal communication. It established the territorial planning issues in a real and objective relationship with the environmental, economic and social issues affecting long-term development. It brought all of the sectorial policies under one single framework and designed a model for sustainable spatial development for the next 15 years for the country to follow. It served as a school for capacity building and increased knowledge related to territory management issues for many ministries and government agencies that until then were operating under single isolated sector issues, ignoring the bigger picture that spatial planning can provide. Thus NSP the Albania 2030 conveys a vision of the future territory of Albania following the principles of Territorial Cohesion. In its aims and guidelines it provides a general source of reference for actions with a spatial impact, taken by public and private decision-makers so that policy interventions can be better targeted and thus they can support more effectively the development the country and the use of its so far unrecognized or underexploited territorial potentials.

\section{Planning as an ongoing challenge. Next steps for implementing Albanian NSP 2030}

The challenge lies on how the NSP can be implemented and better adopted when the concepts where it is based are flexible and fluid? How can principles and policies coordinated with developed concepts of European countries, break down to actions and concrete measures for implementation? Considering the above, the steps being pursued by the working group in the implementation of the NSP and the realization of its objectives are:

- Drafting a monitoring platform for the implementation of the NSP. We are working by carefully translating the policies and objectives of the NSP into key indicators, by measuring these we can track the way the plan is being implemented. Many countries have develop national indicators, and also EU programs such as KITSCAP have proposed a set of limited data that can produce indicators that indicate the sustainable and cohesive development of the EU countries. Fundamental to our in-house work has resulted the co-operation with domestic institutions of statistics such as INSTAT and monitoring agencies.

- Meetings with the academic institutions and universities to further explore new and more efficient ways to improve the ongoing territorial management process, but at the same time make territorial cohesion issues part of the local universities research programs related. This not only to address the coherent challenges of spatial development but also to build models of best cases and to forecast the future role of the country when in EU.

- Meetings with local government focusing on the most disadvantaged municipalities in development, to explore more ways to implement NSP and benefit from the national policies that the document provides for them.

- Meet with all the municipal technical staff for the establishment of a municipal data system that will help to measure the realization of NSP objectives in terms of polycentrism, access to services, economic growth, environmental protection, innovation at the same time addressing spatial disparities and more.

- Continuous communication with ministries for the implementation of national strategic projects that integrate the country's economy with the region.

- As well as communication and cooperation with Regional Agencies to promote balanced regional development.

\section{Conclusions}

The NSP Albania 2030 is a fine example showing that territorial cohesion policies and actions can be adopted and implemented with success even when down scaled at national levels.

Interinstitutional collaboration and public communications are the best direct methods to achieve awareness on territorial planning and on sustainable development issues.

The success of flexible planning instruments and the application of open methods of communication depends on the consolidation of institutions in charge of planning coordination. In relation to the latter, NSP remains still a document that seeks to be fully perceived in the heart of its objectives by the policy makers and the government entities that deal with territorial management and development. The enforcement role of NTPA, as governmental institution to achieve the above mentioned objectives is indispensable for Albania, not only for national territorial cohesion achievement but for strengthening the position of the country in the region and implementing a long lasting vison for sustainable spatial development. Last but not least, it was shown that while talking about territory cohesion, "time" which lies between countries and EU integration, is also in planning, relative and a variable that can be stretched and pressed depending on the results and actions that are taken under the sustainable spatial development process. Therefore, in European studies and platforms related to developing and implementing territorial cohesion and sustainable spatial planning, countries like Albania outside the Union, and even more the Balkans, should not be excluded, on the contrary involved, as the benefits of cohesion overcome formal boundaries. 


\section{References}

[1] Böhme, K. and E. Gløersen (2011) Territorial Cohesion Storylines: Understanding a Policy Concept. Spatial Foresight Briefing 2011:1. Luxembourg. www.spatialforesight.eu

[2] European Commission, (1999). ESDP Towards Balanced and Sustainable Development of the Territory of the European Union

[3] Faludi, A (2004)Territorial Cohesion: Old (French) Wine in New Bottles?Urban Studies, Vol. 41

[4] Faludi, A. (2006) From European Spatial Development to Territorial Cohesion Policy, Regional Studies, 40 (6): 667-678.

[5] Faludi, A(2006), Policy Debate From European Spatial Development to Territorial Cohesion Policy, Regional Studies, Vol. 40.6

[6] Ministry of Urban Development (2014) "Policy Document on Territorial Planning and Development 2014-2018", Tiranë

[7] Medeiros, E (2016) Territorial Cohesion: An EU Concept

[8] NTPA (2016) General National Spatial Plan Albania2030, Ministry of Urban Development, National Territorial Planning Agency

[9] EC (2008) Green Paper on Territorial Cohesion. Turning territorial diversity into strength. Communication from the Commission to the Council, The European Parliament, The Committee of the Regions and the European Economic and Social Committee, October 2008, Brussels.

[10] Vogelij 2010

\section{Author Profile}

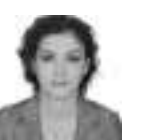

Anisa Qorri ${ }^{1}$ graduated as architect at the Polytechnic University of Tirana, Department of Architecture, Albania. After two years practicing architecture and urban planning in the private sector she pursued further studies and specialized in Spatial Planning and GIS Applications, where she holds a Master Degree. Since 2009 she has been working at the National Territorial Planning Agency (NTPA), Ministry of Urban Development in Albania. During this time within NTPA she has been working on national planning legislation reform, and assisting local and national planning authorities on drafting their planning instrument in line with national planning guidelines. From 2013-2016 she was the team leader for drafting the first National Spatial Plan for Albania. She is now the director of the National Planning Department at NTPA and also invited lecturer at the Faculty of Architecture and Urbanism, in Tirana, Albania.

Eled Fagu $^{2}$ graduated in Architecture at the University of Florence, Italy in 2006. Initially, he was engaged in teaching at different architecture universities in Albania, where he was a lecturer on subjects of composition and theory of architecture and urban design. Since 2014 he has joined the academic staff of the Faculty of Architecture and Urbanism, Polytechnic University of Tirana. Currently he is pursuing the doctoral studies with a thesis on history and criticism of urban and architectural design, focusing on the birth and development of cities established during the period of Socialist Realism in Albania. His research interests also include topics that address issues of theory of architecture and urban design.

Volume 6 Issue 12, December 2017 